\title{
Environmental change and the task of the human resource manager
}

\author{
R.J. van Wyk \\ Unit for the Study of Technological Innovation, University of Stellenbosch, Stellenbosch
}

The analysis of change has become a major preoccupation of modern business managers, including the human resource manager. However, although there is much interest in the analysis of change, there is no single descriptor that captures change adequately. There is no science of change and no academic subject that deals with all the complexities of change. One approach to the analysis of change is to employ a scanning model to identify and observe certain persistent long-term patterns of change. Such a model or checklist can be derived from the environmental hexagon, a modern, highly differentiated, concept of the business environment. The application of this environmental model in the South African business setting is illustrated and a number of long-term trends are described. Against this background certain tasks of the human resource manager are described. First, he should be perceptive of change and should be seen to be perceptive. Second, he should encourage the appointment of personnel who's task it is to observe and interpret change. Third, he should contribute towards rounding out the skills of his colleagues to equip them to observe and interpret change. Fourth, he should compile and evaluate a menu of suitable training experiences for his personnel. Fifth, he should evaluate carefully where and when to use these inputs in his organization. Tine changing environment is redefining the role of the human resource manager and is placing greater emphasis on flexibility and creativity.

S. Afr. J. Bus. Mgmt. 1985, 16: $71-75$

Die ontleding van verandering is ' $n$ belangrike taak van die moderne sakeleier, insluitend die menslike-hulpbronbestuurder. Nieteenstaande die bree belangstelling in hierdie veld is daar geen enkele maatstaf wat verandering voldoende beskryf nie. Daar bestaan geen wetenskap van verandering nie en geen akademiese vak wat die onderwerp ten volle behandel nie. Een metode om verandering te bestudeer is om sekere langtermynneigings uit te ken en te ontleed. 'n Model of kontrolelys hiervoor kan afgelei word van die 'omgewingseshoek'-model van die sake-omgewing. Die toepassing van so ' $n$ omgewingverkenningsmodel in die SuidAfrikaanse sakemilieu word geïllustreer en ' $n$ aantal langtermyntendense word beskryf. Teen hierdie agtergrond word etlike take van die menslike-hulpbronbestuurder uitgeken. Eerstens moet hy homself instel op die waarneming van verandering en moet hy raak. gesien word as iemand wat daarop ingestel is. Tweedens moet hy die aanstelling van mense wie se taak dit is om verandering waar te neem en te vertolk aanmoedig. Derdens moet hy bydra tot die uitbou van die vaardigheid van sy kollegas ten einde hulle toe te rus om hierdie taak te vervul. Vierdens moet hy kennis opdoen van verskillende herorièntasieprogramme wat deelnemers aanhelp om verandering waar te neem. Vyfdens moet hy vasstel waar en hoe hierdie insette binne sy organisasie benut behoort te word. Die veranderende sake-omgewing herdefinieer dus die rol van die menslike-hulpbronbestuurder en verg groter aanpasbaarheid en skeppingsvermoè van sy kant.

S.Afr. Tydskr. Bedryfsl. 1985, 16: 71-75

Keynote address: Annual Convention of the Institute for Personnel Management (Southern Africa), Sun City, Bophuthatswana, September 1983

R.J. van Wyk

Unit for the Study of Technological Innovation, University of

Stellenbosch, Stellenbosch, 7600 Republic of South Africa
Many of us share the common interest of concern with the impact of change on our corporate lives, and yet each of us would be hard pressed to describe in simple and unpretentious terms the essence of that change which fascinates us so.

Change is pervasive. Look behind every crisis or brilliant achievement and one finds an element of novelty, something that was not there before. At the same time change is elusive. Under the eye of the observer that which was a grub, imperceptibly turns into a butterfly, a whole new being emerges, but the individual patterns and lines of transmutation are hard to pry apart and unfold clinically.

How then does the manager deal with this liquid mosaic that constitutes his business setting?

Does he rely largely on his intuition? Does he enter a state of 'relaxed awareness' and allow his managerial maturity to convey to him a feeling for what is happening out there? Or should he pursue the explicit understanding of the business setting, creating conceptual frameworks independent of his own internal images, frameworks that can be conveyed to and shared with others?

The answer is very much a question of personal style, some of us preferring the soft approach of relaxed awareness, some the hard approach of explicit analysis.

My own preference would be for the second option, i.e. the option of explicit analysis. This preference stems not so much from the belief that the explicit approach is superior to the other, but from the realization that it can be shared, it can be taught, and it can be imbedded in formal corporate procedures. In short it can be managed.

In pursuing this approach four aspects will be touched upon. First, the question of an appropriate paradigm for analysing change. Second, a look at the concept of the corporate environment. Third, searching for trends. Fourth, a brief review of the fabric of change that has been observed. And finally, a comment on the human resource manager's role in the management of all this.

\section{In search of a paradigm}

Having chosen the route of explicit analysis the first obvious question that has to be dealt with concerns the conceptual framework for handling change. Is there an accepted intellectual tool that we can readily employ?

As far as I know there is not. There is no single descriptor that adequately captures the features of change that fascinate and befuddle us so. There is no science of change and no academic subject that deals with change fully. In fact we have to start from scratch.

As a first step let me spell out some of the features of 
change that the paradigm we seek will have to contend with.

- The change we are interested in is all around us, it is not limited to one overriding aspect

- Change is persistent, it is not seasonal, cyclical or reversible

- Some strands of change are intertwined with others, there are interactions, reinforcements and camouflage to contend with

- Change is subtle and not always patently obvious.

What paradigm can cope with all this? The one candidate that presents itself, albeit somewhat modestly, is the concept of the business environment.

\section{The corporate environment}

The concept of the business environment was created to capture the idea of the overall setting within which a business operates. It is a very useful concept, stressing the impact of external forces on the continued well-being of the firm and, in its modern form, providing a useful checklist of environmental categories within which individual patterns of change may be identified. (Van Wyk, 1976: 6)

The checklist is based on a framework which has evolved through time from an undifferentiated to a highly differentiated format. This is illustrated in Figures 1-3. Initially the business environment was seen as the economic setting within which the business operates, no more and no less. In fact some business schools to this day teach environmental analysis as if it involved no more than economics. In time the concept of the environment acquired a more differentiated structure as represented by the environmental hexagon.

In this model physical trends refer to patterns of change occurring in nature whether owing to spontaneous causes or to human intervention. Technological trends cover the patterns of evolution in man-made artifacts. These may be concrete such as tools and machines, or abstract such as set procedures, recipes, formulae, and algorithms. Economic trends include changes in the overall level of economic activity such as measured by gross domestic product or its constituent parts, as well as in other measures of macro economic change such as in price levels and employment. Social trends refer to patterns of change in the needs, values, attitudes, and behaviour of people. Political trends reflect changing

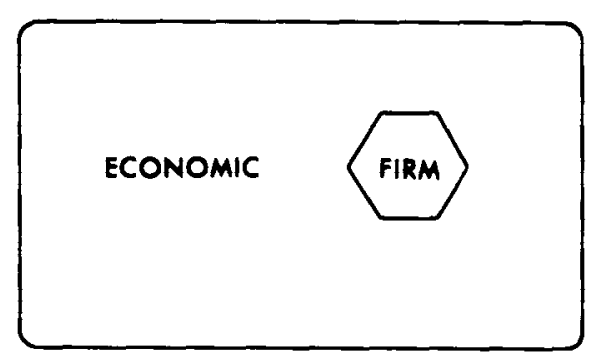

Figure 1 Undifferentiated view of the business environment

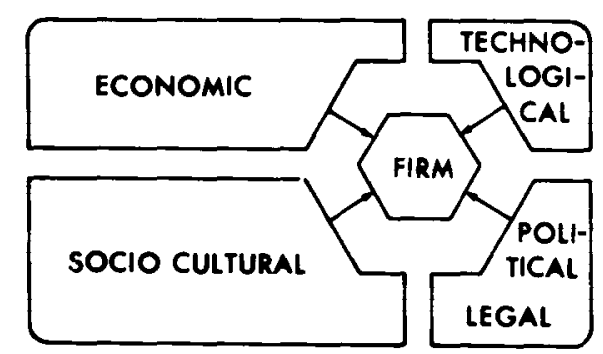

Figure 2 Partially differentiated view of the business environment

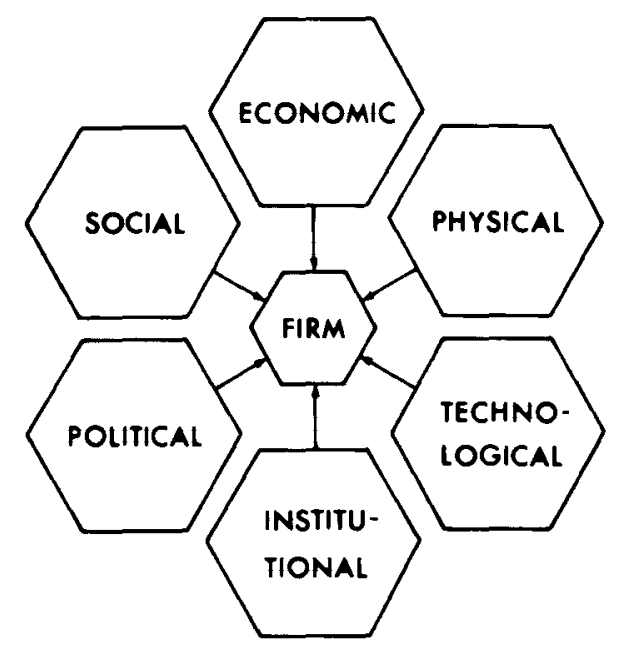

Figure 3 Highly differentiated view of the business environment - Environmental Hexagon

ideologies, patterns of political participation and related issues such as changing power bases. And finally, institutional trends refer to all changes that are manifested through altered legislation, regulation or established rules of conduct.

\section{Choosing specific trends}

Knowing the various environmental categories within which to search for trends the next question concerns the specific trends to be observed. For each environmental category we have to understand the major evolutionary forces present. Ideally this would require:

- A theory of evolutionary change in each of the categories identified

- The theory to be expressed in measurable magnitudes

- The existence of actual measures

- A time series of measurements in each case so that historical patterns of change can be charted and extrapolated into the future.

When applying this 'shopping list' of desired features to each of the environmental categories, we come away slightly aghast at our list of unfulfilled wants.

We find for instance that the economic category is well served. We have interesting theories of economic growth, expressed in measurable terms. Actual measures have been made and adequate historical data bases exist. All in all a satisfactory situation. (Kuznets, 1973).

The physical category, on the other hand, offers a mixed bag. We have extremely interesting issues (Wilson, 1981), much data, and lengthy time series, but little by way of a holistic integrated theory of evolution. This is one area in which the environmental scanner in business would appreciate a more coherent conceptual framework.

In all the other environmental categories there are no generally accepted frameworks as yet. In the case of the technological category a valiant attempt has been made to establish a general theory of technological evolution (Bright, 1964: 12-18; Rapp, 1974 and Van Wyk, 1984). Some attempts have been made at formulating measurable magnitudes. Unfortunately not much has been published in this field and data bases are hard to come by.

In the social, political, and institutional categories broad evolutionary perspectives are not the 'in' thing. However at the empirical level much work is being done to measure attitudinal change in order to generate trends. In this connection the work of the Institute for Futures Research at Stellenbosch (Dostal, 1984) and of at least three other organizations should 
be noted (Market Research Africa; Markinor, 1980 and Indicator).

In spite of the theoretical shortcomings much know-how has been accumulating in connection with environmental scanning and the documentation of broad patterns. Many companies have developed in-house monitors of environmental change, and the Institute for Futures Research has defined environmental monitoring as its mission.

The pleasing thing about these exercises is that they focus on major or overriding trends, i.e. those patterns of change representing the major forces operating within each category. In this context the word 'trend' is used in its mathematical context as meaning a persistent and continuous change in the value of a given magnitude. The more popular meaning of the word indicating 'the latest or the newest' would not be suitable here.

We may now turn to an examination of some of these trends.

\section{The fabric of change}

The following patterns of change are offered as examples of the type of trends which an analyst of change will observe. They are not intended as an overall review but merely snippets for purposes of illustration (Van Wyk, 1982).

\section{Physical trends}

Various indicators suggest that the climate of the past 100 years has been extremely favourable and unusually warm. The probability of 15 years of similar climatic conditions is very small. A long-term cooling trend appears to have persisted for the past 5000 years with marked subperiods of acceleration and deceleration. Since 1950 a period of accelerated cooling appears to have set in (Dostal, 1979).

In contrast to this 'spontaneous' trend, a warming pattern has been observed directly attributable to human industrial activity. At this stage it is difficult to foresee how these two trends will interact and what global or regional turbulences could arise as a result thereof.

However in South Africa strong evidence exists of changing climatic boundaries, a phenomenon popularly referred to as Karoo penetration. The extension of the Karoo is said to be proceeding at the rate of hundreds of meters per annum. (Clarke, 1974).

Against this climatological background the next question concerns living beings, what is happening to people, animals and plants? The number of humans are increasing dramatically - South Africa behaving in this respect very much as an underdeveloped nation with a veritable population explosion.

The number and variety of naturally occurring plants and animals are declining steadily. Those suitable for human exploitation are diligently cultivated and becoming ever more standardized.

Natural resources, especially of the non-renewable variety, are showing signs of heavy exploitation. For instance while we have some of the highest population growth rates in the world we only have half the world's average rainfall. New patterns of relative scarcities will therefore emerge which will enforce changes in human industrial behaviour. Among other things this has occasioned a shift from 'wet' to 'dry' cooling procedures at thermal power stations.

\section{Economic trends}

Future economic trends will be greatly influenced by the population growth rates referred to above. The age and racial composition of the nation will change significantly and the dependency factor will increase owing to the large number of babies being born. This population growth is such as to raise serious questions about the capacity of the economy to generate employment and to provide the necessary social infrastructure in the form of homes, schools and hospitals.

As far as the long-term economic growth potential of the economy is concerned, rates in the region of $4 \%$ have come to be regarded as achievable provided certain conditions can be met. Read together with the population growth rates this projection no longer places South Africa in the top league of economic performers.

Inflationary pressures are projected to remain at a high level. Obviously some prices will inflate more rapidly than the average while others will inflate at lower rates. Some of the greatest price increases in the recent past have been in the field of black wages and this could quite well remain the biggest inflationary force for some time to come.

Differential patterns in the growth of incomes will cause the aggregate demand profiles of the nation to change as new sets of consumer values and preferences emerge in the market.

Unfortunately the combined effect of high population growth and escalating wage rates could create a high potential for unemployment which seems destined to become an uncomfortably persistent feature of the South African economy.

\section{Technological trends}

Of the many patterns of change that characterize the overall process of technological evolution three in particular seem to have a direct bearing on the South African situation.

First, there is the growing competence of computers and their proliferation into a wide variety of information-handling devices associated with the regulation and control of industrial processes. Closely related to this trend is the emergence of industrial robots, i.e. highly versatile, reliable and programmable machines that assemble parts or, as tool handlers, perform skilled tasks. The predominant trends that characterize their evolution are increasing competence and falling real costs.

Second, there is steady progress towards the internal regulation of the growth and function of living organisms through the control of their central information store, i.e. their so-called 'recipes for existence'. This implies a whole new potential for production processes based on biological organisms. It also reminds us that where living organisms were regarded as nature's gifts in the past, they will be regarded more and more as the products of human know-how in the future. They will therefore be increasingly protected by patents and licencing agreements.

Third, a growing preoccupation with clean sources of energy i.e. solar, wind and tidal energy. This brings into focus possibilities beyond coal gasification and liquifaction, and uranium enrichment so well enunciated in South Africa.

The increasing technification of agriculture, mining and manufacture is inevitable. A high level of technical competence will be required to understand, evaluate and successfully implement the new technologies. New frontiers of understanding will be required to integrate these successfully into an industrial setting noted for its rapidly escalating wage rates and surplus labour.

\section{Social trends}

It is frequently held that individual behaviour is conditioned by individual attitudes which in turn are controlled by personal 
values which, finally, are a function of human needs.

With persistent economic growth and differential wage escalation rates the aggregate need profile of the population is undergoing significant change. This will inevitably lead to a restructuring of values and attitudes which, in turn, will cause a high state of flux in human behaviour in South Africa.

Not much experience exists in this country for measuring and monitoring social trends but benchmark surveys referred to earlier are now underway to establish a basis from which to evaluate future developments.

\section{Political trends}

Changing social needs eventually become reflected in changing political attitudes. Groups whose future seems secure and who live with a high level of expectation of what the future holds in store for them seem to loose much of their sense of militancy. On the other hand the level of militancy increases among people who feel their future threatened and who fear unwanted inroads into their way of life.

Within a framework of ever-changing political pressures South Africa has entered into a phase of significant political restructuring. The trend is difficult to describe. The direction is an open-ended one although closely managed. An extremely precarious route is seen for the nation which is now attempting to fuse strongly traditional democratic and non-democratic views into a stable and viable structure.

\section{Institutional trends}

With an ever-changing business environment it may be expected that organizational forms will have to undergo a measure of restructuring as well. The functional divisions of most organizations functioning at present can, for instance, be traced back to French models of nearly 70 years ago, i.e. those of Henri Fayol.

New concepts are emerging to challenge the old. The Fayol concept which gave us the classification of general management, marketing, finance, production, accounting, and security (and please note no personnel function) is being challenged by alternative notions such as Lievegoed's. He emphasizes not so much the nature of activities being carried out, as the categories of typical skills required. In this respect he distinguishes four areas of management, namely human relations management, resource management, process management, and information management. (Lievegoed, 1973).

Organizations are feeling the strain of constantly having to rethink their own structures and are searching for new and powerful concepts.

\section{Change needs management}

We now come to a very down to earth and practical point. What should the position of the human resource manager (HRM) be in relation to the phenomenon of change?

The most important thing to realize is that one is dealing here with a situation literally vibrating with creative potential. When so many forces converge, tensions build up which can spark off new visions and insights to provide the driving force for meaningful development.

Also the HRM must acknowledge that he is facing the unique challenge of managing unstructured thoughts in a structured environment. The urge to look for patterns of change, the skill to read them and the willingness to interpret them requires courage and individuality that can easily be misunderstood in the suave and sophisticated corporate setting.
Having sounded these warnings, what should the HRM set about doing?

First task: The HRM should overhaul himself. He should be perceptive of change, and be seen to be perceptive

This is a subtle but important point. If the HRM does not give sufficient attention to understanding broad patterns of change he can hardly hope to understand and relate to people who do. The danger in this respect is that the HRM is frequently seen as somebody who pays lip service to change but is in himself extremely narrow and only interested in things with a psychological dimension. (Test yourself, how interested are you in, for instance, voice-activated technology, robots, Karoo penetration and differential price movements?)

Second task: Encourage the existence of personnel whose task it is to observe and interpret change

Many modern enterprises employ people whose job it is to observe and interpret patterns of change. Sometimes they are called environmental scanners, sometimes corporate planners, and sometimes even economists. Frequently they are rare and gifted individuals, and sometimes they are found in the planning department. The HRM should identify the locus of this type of activity and encourage it if it does not exist.

Third task: Contribute towards the rounding out of the skills of colleagues

To be able to observe and integrate a broad spectrum of trends, people require a balanced profile of basic business disciplines. In this context a useful rule of thumb is to consider the trilogy 'MFT', meaning market, finance and technology. (When speaking of skills in this context we are obviously referring to task skills in addition to the acknowledged personal skills like reasoning, relating and relaxing). Most managers are not too bad on marketing and finance but are clumsy when it comes to technology. Also very few business schools foster a rounded managerial perspective which includes the technological aspect. In fact the position is so bad that the next broadly striking national crisis in South Africa could quite well be technology related.

Fourth task: Compile and evaluate a menu of suitable training experiences

As the custodian of training the HRM has the task of finding and retaining knowledgeable persons who can be called upon to help introduce the concepts of change management into his firm. He will have to choose at which of three levels assistance will be required.

- Scanning - to create awareness of change

- Monitoring - to keep abreast of predominant patterns of change

- Forecasting - to try and look ahead in areas of vital concern for the enterprise.

Each of these types of activities requires special skills and procedures. The HRM must be sure he knows what he wants and what he is getting. Furthermore his brief to outside experts must be clear and specific. Experience has shown that the policy of 'It might be a good idea to have so-and-so come and have a talk to our chaps' can be a spectacular disaster and can harm, more than encourage, an awareness of change.

Fifth task: Carefully evaluate where to slot these inputs from outside into the organizational processes

The HRM must develop an astute awareness of the problem 
of integrating external observations into the firm's own corporate procedures. For instance a well-structured environmental scanning exercise such as is available in a standardized format is a delightful unfreezing exercise for management and a useful and logical kick-off to events such as a strategic planning session, a search for diversification opportunities, or a new product-screening exercise. However, it is out of place in a setting dealing with issues such as market analysis, budgeting, and job evaluation.

\section{Conclusion}

Although it is difficult to describe change accurately, some fascinating new paradigms have emerged to facilitate the observation and analysis thereof.

Scanning, with its emphasis on environmental trends, has provided a modest but useful insight into change analysis procedures.

Examples of environmental trends in South Africa suggest a new business scene based on a labour-surplus, resourcestretched, economy functioning within a possibly more hostile physical environment. A danger exists that many people will be excluded from the central hub of economic activity. New technologies will permeate the business scene without their import and impact being fully understood or anticipated. New social attitudes will arise stemming from higher levels of wellbeing among some and relative stagnation among others. Consequently a new need profile will make itself felt. This will occur in a political setting beset with the anxieties of fundamental restructuring. All this will call forth changing organizational structures.

The HRM will play a key role in this highly creative yet liquid mosaic, provided he is attuned to change, in communication with those in the organization that observe change, know what resources he can mobilize to assist in scanning, monitoring and forecasting change, and can ensure that informational inputs on environmental change flow into his organization at the correct, and adequately prepared, level.

\section{References}

Bright, J.R. 1964. Opportunity and threat in technological change. Research Development and Technological Innovation. Homewood, Illinois: Richard D. Irwin, 783 p.

Clarke, J. 1974. Our fragile land. Cape Town: Macmillan, $134 \mathrm{p}$.

Dostal, E. 1979. Climate change to the year 2000. Stellenbosch: Unit for Futures Research, University of Stellenbosch, $10 \mathrm{p}$.

Dostal, E. 1984. The future of South Africa: A survey among leaders of the major South African institutions. Stellenbosch: University of Stellenbosch, $50 \mathrm{p}$.

Indicator Project South Africa 1983 (Published quarterly), Indicator, a barometer of social trends. Durban: University of Natal, Centre for Applied Social Sciences.

Kuznets, S. 1973. Modern economic growth - It's rate structure and spread, New Haven: Yale University Press, $529 \mathrm{p}$.

Lievegoed, B.J.C. 1973. The developing organization. Translated from the Dutch by J. Collis, London: Tavistock, $271 \mathrm{p}$.

Market Research Africa: (Bi-annually), SOCIOMONITOR, Johannesburg.

Markinor: 1980 (published six monthly), Socio-political barometer. Johannesburg.

Rapp, F. (Ed.). 1974. Contributions to a philosophy of technology. Boston: Reidel, 228 p.

Van Wyk, R.J. 1984. Panoramic scanning and the technological environment. Technovation, vol. 2, $101-120$.

Van Wyk, R.J. 1982. Futuristics, the Stellenbosch experience. Finance Trade Rev., vol. 15, 58-71.

Van Wyk, R.J. 1976. A review of some long-term trends in South Africa, Stellenbosch, Unit for Futures Research, 75 p.

Wilson, L.S. 1981. The world's changing climate, some isues for planners. Long Range Plann., vol. 14, 83-89. 